For citation: Barkordari, S. \& Fattahi, M. (2017). An Equilibrium Aggregate Demand and Supply Model to Examine the Dynamic Effect of Oil Price Shocks on Output and Inflation in Iran as an Oil Exporting Country. Ekonomika regiona [Economy of Region], 13(3), pp. 839-846

doi 10.17059/2017-3-16

UDC: 338

JEL: C32, E31, E23

S. Barkordari ${ }^{\text {a) }}$, M. Fattahi ${ }^{\text {b,c }}$

a) University of Tehran (Tehran, Iran; e-mail: barkhordari@ut.ac.ir)

b) University of Tarbiat Modarese (Tehran, Iran)

c) and Islamic Azad University (Tehran, Iran)

\title{
AN EQUILIBRIUM AGGREGATE DEMAND AND SUPPLY MODEL TO EXAMINE THE DYNAMIC EFFECT OF OIL PRICE SHOCKS ON OUTPUT AND INFLATION IN IRAN AS AN OIL EXPORTING COUNTRY
}

Iran is an oil exporting country in Middle East. The high share of the oil revenues in Iran is a serious economic problem. Due to the high dependency of Iran's economy on oil revenues, oil price shocks have a determinant impact on macroeconomic variables. In this paper, we analyze the dynamic effects of oil price shocks and the aggregate supply and aggregate demand shocks on macroeconomic fluctuations in Iran. According to macroeconomic theory and aggregate demand and supply model in equilibrium, a structural vector autoregressive (VAR) model is applied to identify different structural shocks and further assess the relative contributions of different shocks on macroeconomic fluctuations, using a decomposition approach. The results show that oil price shocks have significant and positive effects on both output and inflation. Aggregate supply and aggregate demand shocks are the main causes of fluctuation in output and inflation, and moreover, the effect of aggregate supply shocks on output is permanent in the Iranian economy. On the base of this study results, we suggest the Iranian government should accelerate the economic reforms such as the finance system of state owned enterprises, the tax system, the cash subsidy distribution system, the allocation system of the government budget in national and provincial level, the financial and banking system, and so on. The suggested reforms aim to decrease in the share of oil revenues in the economy and protect the Iranian economy in the face of any exogenous and endogenous shocks.

Keywords: macroeconomic fluctuations, oil price, aggregate demand, aggregate supply, structural model, structural VAR model, resilience economy, economic shocks, Iranian economy, government

\section{Introduction}

The oil price shocks of 1973 and 1974 and the consequent recessions in the United States and other developed countries prompted researchers to examine the effects of such shocks on the macro economy more rigorously. Some studies investigate theoretical mechanisms and channels through which the oil price increase might retard economic activity [1]; [2]; [3]. Some studies [4-8] have indicated a linear negative relationship between oil price and real economic activity. Since the decrease in the oil price had a positive effect on real economic activity up until the end of these 1980s, the models focused on the asymmetric effect specifications. Examples of such studies are those conducted by $[2,9,10]$.

\footnotetext{
${ }^{1}$ Barkordari S., Fattahi M. Text. 2017.
}

Studies on modeling the oil price shock and its effects on economic activity have shown differences based on the methodology of the above-mentioned studies. Some notable studies on these topics have been by [11-17].

One common feature in most of the previous studies was their focus on developed countries, such as the United States and European countries, and relatively less attention has been paid to Asian economies, especially oil exporting countries, despite their increasing importance in the oil market. A few of the previous studies on Asian countries are by [18-21].

Iran is an important oil exporting country in Asia and fluctuation in oil price affects the Iranian economy from both the demand and supply side aspects. The results of some studies on Iran show that a change in oil price impacts the trade balance, inflation, unemployment, economic growth, and exchange rate [22-26]. The summary of stud- 
Table 1

The summary of studies about Iranian economy

\begin{tabular}{|c|c|c|c|}
\hline Study & Sample period & Methodology & Results \\
\hline Shakibaei et al. (2008) & $\begin{array}{l}\text { Monthly data } \\
(1995: 1-2006: 12)\end{array}$ & Panel Data & $\begin{array}{l}\text { There is a long-run relationship between oil price } \\
\text { and exchange rate }\end{array}$ \\
\hline $\begin{array}{l}\text { Farzanegan and } \\
\text { Markwardt (2009) }\end{array}$ & $\begin{array}{l}\text { Quarterly data } \\
(1975: \text { II-2006:IV) }\end{array}$ & $\begin{array}{l}\text { Unrestricted VAR } \\
\text { model }\end{array}$ & $\begin{array}{l}\text { The oil price shocks significantly increase inflation } \\
\text { and there is a strong positive relationship between } \\
\text { positive price changes and industrial output } \\
\text { growth }\end{array}$ \\
\hline $\begin{array}{l}\text { Nemati Allahi et al. } \\
(2009)\end{array}$ & $\begin{array}{l}\text { Annual data } \\
(1967-2006)\end{array}$ & ARDL & $\begin{array}{l}\text { The changes of oil price have a negative and } \\
\text { significant effect on the balance of trade. }\end{array}$ \\
\hline Ebrahimi et al. (2010) & $\begin{array}{l}\text { Quarterly data } \\
\text { (1988:I-2007:IV) }\end{array}$ & SVAR & $\begin{array}{l}\text { The shocks of oil price increase liquidity, } \\
\text { government spending and inflation }\end{array}$ \\
\hline Jahadi and Elmi, (2011) & $\begin{array}{l}\text { Annual data } \\
(1970-2008)\end{array}$ & VAR & $\begin{array}{l}\text { Iran and United Emirate Arab have a heavy } \\
\text { dependence on oil, while, Indonesia and Ecuador } \\
\text { have low dependence }\end{array}$ \\
\hline Farzanegan (2011) & $\begin{array}{l}\text { Annual data } \\
(1959-2007)\end{array}$ & $\begin{array}{l}\text { Unrestricted VAR } \\
\text { model }\end{array}$ & $\begin{array}{l}\text { Iran's military and security expenditures } \\
\text { significantly respond to a shock in oil revenues } \\
\text { and social spending does not react to such shocks. }\end{array}$ \\
\hline Esfahani et al. (2013) & $\begin{array}{l}\text { Quarterly data (1976: } \\
\text { I- 2006: IV) }\end{array}$ & $\mathrm{VARX}^{*}$ model & $\begin{array}{l}\text { Real output in the long-run is influenced by } \\
\text { oil exports and foreign output. Inflation has a } \\
\text { significant negative long-run effect on real GDP }\end{array}$ \\
\hline Faraji Dizaji (2014) & $\begin{array}{l}\text { Annual data (1970- } \\
\text { 2008) and quarterly } \\
\text { data (1990: II- 2009: I) }\end{array}$ & SVAR model & $\begin{array}{l}\text { The contribution of oil revenues shocks is stronger } \\
\text { than the contribution of oil price shocks in } \\
\text { explaining the government expenditures }\end{array}$ \\
\hline Khiabani (2015) & $\begin{array}{l}\text { Quarterly data (1988: } \\
\text { II- 2013: IV) }\end{array}$ & SVAR model & $\begin{array}{l}\text { Oil price shocks have a positive and persistent } \\
\text { effect on housing activities }\end{array}$ \\
\hline $\begin{array}{l}\text { Mohseni and } \\
\text { Jouzaryan (2016) }\end{array}$ & $\begin{array}{l}\text { Annual data } \\
(1996-2012)\end{array}$ & ARDL model & $\begin{array}{l}\text { Inflation and unemployment have a negative and } \\
\text { positive effect on economic growth in long-run, } \\
\text { respectively }\end{array}$ \\
\hline
\end{tabular}

ies that focused on Iranian economy is reported in Table 1.

In previous studies, the effects of oil price shocks on economic variables were studied with the econometric models without attention to the Iranian macroeconomic framework in equilibrium. Also, the previous studies focused on oil price shocks only. This paper attempts to fill these gaps by addressing how and to what extent oil price, demand, and supply shocks impact Iranian economy in the macroeconomic framework assumed Lucas supply curve and an aggregate demand and supply model in equilibrium. Hence, this paper analyses the economic impact of oil price shocks on the Iranian economy. We are interested in the nature of oil price, demand and supply shocks, and how they affect macroeconomic fluctuations in Iran's economy as an oil exporting country. Here, the major purpose of this paper is to explore oil price shocks and their short-run and long-run effects on the Iranian economy.

Following this, the paper organized as follows: section (2) explains Iran's economic situation. Sections (3) and (4) explain the model specification, method and data. Section (5) discusses the empirical results and finally, section (6) is dis- cussion and conclusion that provides summary reports of conclusions and the policy implications of the findings.

\section{Economic Background of Iran}

Iran is an important oil producer within the Organization of Petroleum Exporting Countries (OPEC) and the income from oil and gas exports plays a leading role in the Iranian economy. The sixty and seventy percent of total export earnings and 30-40 percent of the annual government budget depend on oil and gas export revenues. Also, the share of the oil and gas sector in Iranian GDP is approximately 11 percent [27]. In this condition, any world oil price shock can have a determinant effect on macroeconomic variables.

Any shock in the price of oil affects government expenditure, consumption, investment and production in the Iran's economy. In recent years, the intensification of sanctions on the Iranian economy in 2010 decreased oil export and oil incomes. The consequent decreasing in oil income caused, on the one hand, a decrease in economic growth in 2013, on the other hand, inflation in Iranian economy increased because the exchange rate (USD against IRR) has risen by about 


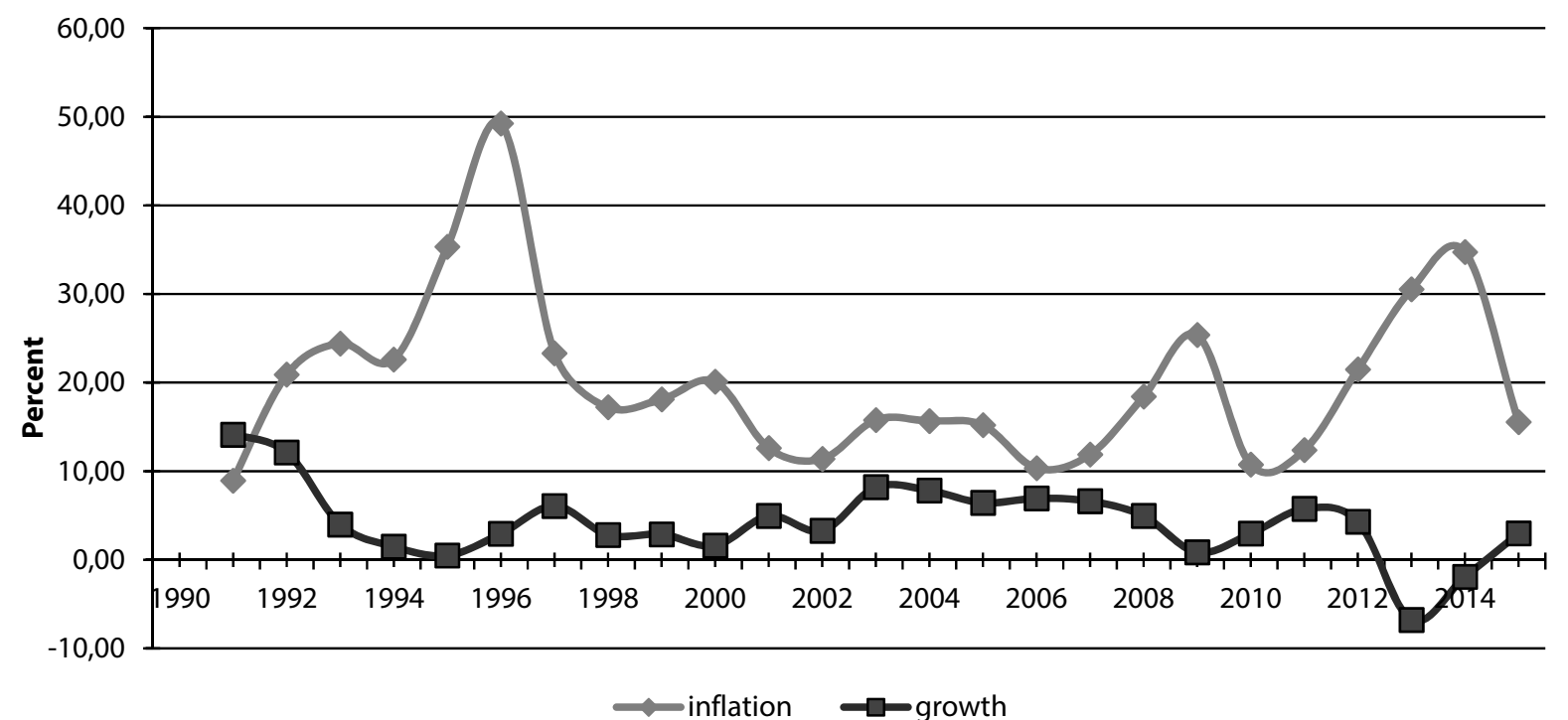

Fig. 1. Annual economic growth and inflation 1990-2014

three fold. Also, in 2015, the decrease in oil price reduced the economic growth in Iran to about 1 percent. Therefore, any shock in oil price has a determinant effect on macroeconomic variables in Iran's economy. Figure 1 shows the economic growth and inflation in the period of 1990-2014.

In the present study, we consider the dynamic effects of oil price shocks on Iran's economy. Also, we study the effects of aggregate demand and aggregate supply shocks on output and inflation in a structural framework. The main aim of this study is to make policy makers aware of the dynamic effects of oil price shocks on output and inflation. In addition, the results of this study aim policy makers to support the Iranian economy against shocks, especially oil price shocks.

\section{Model Specification}

The model applied in this paper is an aggregate demand and supply model, and we assume a Lucas supply curve $[28,29]$ with rational expectations:

$$
y_{t}^{s}=\bar{y}_{t}+\alpha\left[p_{t}-E_{t-1}\left(p_{t} \mid \Omega_{t-1}\right)\right],
$$

where aggregate supply $\left(y_{t}^{s}\right)$ is a function of natural rate of output $\left(\bar{y}_{t}\right)$ and the difference between actual domestic price level $\left(p_{t}\right)$ and its expectation given all available past information $\left(\Omega_{t-1}\right)$.

Taking expectations on time $t-1$ and rearranging equation (1) gives us:

$$
y_{t}^{s}=E_{t-1}\left(y_{t} \mid \Omega_{t-1}\right)+\alpha\left[p_{t}-E_{t-1}\left(p_{t} \mid \Omega_{t-1}\right)\right]+\eta_{t},
$$

where $\eta_{t}$ represents productivity shocks, which is further decomposed into supply shock and oil price shocks [30]:

$$
\begin{gathered}
y_{t}^{s}=E_{t-1}\left(y_{t} \mid \Omega_{t-1}\right)+\alpha\left[p_{t}-E_{t-1}\left(p_{t} \mid \Omega_{t-1}\right)\right]+ \\
+\varepsilon_{t}^{s}+\beta \varepsilon_{t}^{o p} .
\end{gathered}
$$

High oil price affecting the economy of oil exporting countries, such as Iran and will increase national income through greater oil export revenues, especially for Iran where the oil sector plays such a major role in the economy. It is therefore expected that $\beta>0$ for exporting countries such as Iran. In contrast, the importing countries will respond negatively $(\beta>0)$ due to an increase in marginal costs and inflation.

The aggregate demand is assumed as follows:

$$
y_{t}^{d}=m_{t}-p_{t}+\varphi o p_{t}^{w},
$$

where aggregate demand $y_{t}^{d}$ is a function of money $\left(m_{t}\right)$, domestic price level $\left(p_{t}\right)$ and world oil price $\left(o p_{t}^{w}\right)$. Similarly as for the supply side, taking conditional expectations on time $t-1$ and rearrange equation (4), gives us:

$y_{t}^{d}=E_{t-1}\left(y_{t} \mid \Omega_{t-1}\right)-\left[p_{t}-E_{t-1}\left(p_{t} \mid \Omega_{t-1}\right)\right]+\varepsilon_{t}^{d}+\xi \varepsilon_{t}^{o p}$.

We assumed $\xi>0$ for oil exporting countries such as Iran, which implies that high oil price increases the demand level, because government expenditures in these countries will increase.

The economy is in equilibrium when,

Hence we have,

$$
y_{t}^{s}=y_{t}^{d}=y_{t} .
$$

$$
\begin{aligned}
p_{t} & =E_{t-1}\left(p_{t} \mid \Omega_{t-1}\right)-\left(\frac{1}{1+\alpha}\right) \varepsilon_{t}^{s}+ \\
& +\left(\frac{1}{1+\alpha}\right) \varepsilon_{t}^{d}+\left(\frac{\xi-\beta}{1+\alpha}\right) \varepsilon_{t}^{o p}, \\
y_{t} & =E_{t-1}\left(y_{t} \mid \Omega_{t-1}\right)+\left(\frac{1}{1+\alpha}\right) \varepsilon_{t}^{s}+ \\
& +\left(\frac{\alpha}{1+\alpha}\right) \varepsilon_{t}^{d}+\left(\frac{\alpha \xi+\beta}{1+\alpha}\right) \varepsilon_{t}^{o p},
\end{aligned}
$$


Table 2

Unit root tests

\begin{tabular}{|l|c|c|c|c|c|c|c|c|}
\hline \multirow{2}{*}{} & \multicolumn{3}{|c|}{ Augmented Dickey-Fuller (ADF) test } & \multicolumn{4}{c|}{ Phillips-Perron (PP) test } \\
\cline { 2 - 9 } & \multicolumn{2}{|c|}{ without trend } & \multicolumn{2}{c|}{ with trend } & \multicolumn{2}{c|}{ without trend } & \multicolumn{2}{c|}{ with trend } \\
\hline Variables & Level & first diff. & Level & first diff. & Level & first diff. & Level & first diff. \\
\hline Real oil price $\left(o p_{t}\right)$ & -1.05 & $-8.71^{* *}$ & -2.98 & $-8.66^{* *}$ & -1.11 & $-7.16^{* *}$ & -2.76 & $-7.02^{* * *}$ \\
\hline Real GDP $\left(y_{t}\right)$ & -1.28 & $-4.66^{* *}$ & -1.52 & $-4.77^{* *}$ & -2.02 & $-19.84^{* * *}$ & -2.6 & $-19.69^{* * *}$ \\
\hline Domestic price level $\left(p_{t}\right)$ & -0.21 & $-3.26^{* *}$ & -1.83 & $-3.16^{*}$ & -0.57 & $-6.22^{* * *}$ & -1.59 & $-6.23^{* *}$ \\
\hline
\end{tabular}

Note: ${ }^{* *},{ }^{* *}$ and ${ }^{*}$ indicate the level of significant at the $1 \%, 5 \%$ and $10 \%$ respectively.

We assume that the world oil price can only be affected the shocks related to oil supply and demand, while other factors, such as political events and other non-fundamental phenomena, are considered as exogenous to the oil price. This assumption is true because the Iranian economy is a stable, small and price-taker one. Hence:

$$
o p_{t}^{w}=o p_{t-1}^{w}+\varepsilon_{t}^{o p} \text {. }
$$

Equations (6) - (8) give the structural form model in this paper. In this model, we assume three types of shocks include oil price shocks, $\varepsilon_{t}^{o p}$, aggregate demand shocks, $\varepsilon_{t}^{d}$, and aggregate supply shocks, $\varepsilon_{t}^{s}$, where each structural shock is assumed as white noise and independent from each other. In the short run, oil price, aggregate supply and aggregate demand shocks affect the output level due to the structural form as exhibited in equation (7). We assume aggregate supply shocks have a permanent effect on output, while aggregate demand shocks have only a short run effect [31].

\section{Method and Data}

In virtue of the work of [32], the Vector Auto Regression (VAR), has already become a widely used approach in macro-economy empirical analysis. The VAR approach has exposed to the criticism that it lacks economic interpretations. As [33] indicates, it is not possible to infer the effects of changes in policy rules from a standard identified VAR system, since this approach typically provides little or no structural interpretation of coefficients that make up the lag structure of the model. In contrast, Structural VAR (SVAR) approach incorporates some structures or the economic theory into the analysis. Therefore, we investigate oil price shocks by use of the SVAR approach.

In this study, we use a Structural VAR model with the combination of both short-run and longrun restrictions following [34] to survey the effects of the different shocks on the macroeconomic fluctuation in Iran's economy. We use quarterly time series data include a log of real OPEC oil price, a $\log$ of real GDP and a log of consumer price index (CPI) for the period of $1995 \mathrm{q} 1$ to $2014 \mathrm{q} 4$. The real OPEC oil price was extracted from OPEC sta- tistics and real GDP and CPI were obtained from CBI (Central Bank of Iran).

Before proceeding further, we tested for stationary of the all series using ADF (Augmented Dickey Fuller (1981) and PP (Phillips-Perron (1988)) tests. The results of the unit tests (both ADF and PP tests), are presented in Table 2, indicate that none of the series are stationary at the level, but the first order differences of series are stationary, i.e., all series are integrated of order one (this is mean I(1)).

The reduced form of the model is constructed by the stationary variables. The stationary variables of model include the first difference of log real OPEC oil price $\left(\Delta o p_{t}\right)$, the first difference of real log GDP $\left(\Delta y_{t}\right)$ and inflation $\left(\Delta p_{t}\right)$. We assume the oil price is exogenous and is affected its past (Eq. 8).

We define $z_{t}$ as a vector of stationary variables, $z_{t}=\left(\Delta o p_{t}, \Delta y_{t}, \Delta p_{t}\right)^{\prime}$. The reduced form of $z_{t}$ can be written as:

$$
\begin{gathered}
z_{t}=k+A_{1} z_{t-1}+\ldots+A_{p} z_{t-p}+e_{t}, \\
A(L) z_{t}=k+e_{t}
\end{gathered}
$$

Where $\mathrm{A}(\mathrm{L})$ is the matrix of polynomials lag operator, $z_{t}$ is vector of stationary variables, $e_{t}$ is vector of reduced form residuals with covariance matrix $\Omega$ and $k=\left(k_{1}, k_{2}, k_{3}\right)^{\prime}$ is the vector of intercepts.

The Wold Representation Theorem implies that a stationary process can be represented as an invertible distributed lag of serially uncorrelated disturbances. This implied we can write the Eq. 9 as an infinite moving average process:

$$
\begin{gathered}
z_{t}=C_{0} e_{t}+C_{1} e_{t-1}+C_{2} e_{t-2}+\ldots \\
z_{t}=C(L) e_{t}
\end{gathered}
$$

where $C(L)=A(L)^{-1}$ and $C_{0}$ is the identity matrix.

To go from the reduced form to the structural model, a set of identifying restrictions must be imposed. The elements in $e_{t}$ are orthogonalized by imposing these restrictions. We assume that the vector of structural disturbances as linear combinations of the Wold innovations. So, a form of the moving average can be found as:

$$
z_{t}=D(L) \varepsilon_{t}=D_{0} \varepsilon_{t}+D_{1} \varepsilon_{t-1}+D_{2} \varepsilon_{t-2}+\ldots
$$


where $\varepsilon_{t}=\left(\varepsilon_{t}^{o p}, \varepsilon_{t}^{s}, \varepsilon_{t}^{d}\right)^{\prime}$ are orthogonal structural disturbances.

Equation (10) can be rewritten as:

$$
\begin{gathered}
z_{t}=C_{0} D_{0} \varepsilon_{t}+C_{1} D_{0} \varepsilon_{t-1}+ \\
+C_{2} D_{0} \varepsilon_{t-2}+\ldots=C(L) D_{0} \varepsilon_{t},
\end{gathered}
$$

In the long run, we have:

$$
z_{t}=\sum_{j=0}^{\infty} C_{j} D_{0} \varepsilon_{t}=D(1) \varepsilon_{t}=\left[\begin{array}{l}
d_{11}(1) d_{12}(1) d_{13}(1) \\
d_{21}(1) d_{22}(1) d_{23}(1) \\
d_{31}(1) d_{32}(1) d_{33}(1)
\end{array}\right]\left[\begin{array}{c}
\varepsilon_{t}^{o p} \\
\varepsilon_{t}^{s} \\
\varepsilon_{t}^{d}
\end{array}\right] .
$$

For simplicity, we assume that the structural disturbances are normalized to have unit variance. This assumption, imply that the variance $\varepsilon_{t}$ is as follows:

$$
\operatorname{var}\left(\varepsilon_{t}\right)=\Omega=D_{0} D_{0}^{\prime} .
$$

Due to symmetry in $\Omega$, there are $n(n+1) / 2$ distinct covariances. In this study, we have three variables system, therefore, must impose six restrictions on the elements in $D_{0}$. Three more restrictions are needed for identifying $D_{0}$. First, according to the theoretical model, the real oil prices are free from supply and demand shocks, i.e., the contemporaneous effects of supply and demand on oil price are zero. The two short-run restrictions on real oil prices indicate that:

$$
d_{12}(1)=d_{13}(1)=0 \text {. }
$$

Finally, Blanchard and Quah (1989) assumed that the demand shocks have no effects on the level of output. We impose this assumption as a long-run restriction. This long-run restriction implies that:

$$
d_{23}(1)=0
$$

\section{Empirical Results}

In the SVAR model of this study, the variables are first difference stationary and the level of the variables is not stationary. The lag order of the VAR model is 4 using the Akaike (AIC) and Schwartz (SC) information criteria.

\subsection{Dynamic Effects of Shocks}

In order to explore the effect of structural shock on endogenous variables (output and inflation), we first assess the impulse response functions using structural decomposition through Cholesky method. The impulse response functions are estimated to expose the response of the model to one standard deviation shock to the structural disturbances. We used cumulated impulse response function, which is the cumulated sum of the impulse-response function.
Figures (2) and (3) show the dynamic effects of aggregate supply, aggregate demand and oil price shocks on output and inflation. Also, the dynamic effect of oil price shocks with one standard deviation band around the point estimates are exhibited in Figures 4(a) to (f). These confidence bands are obtained by Monte Carlo simulations with 10,000 replications. The middle lines in the figures indicate the impulse response function while the bands stand for the confidence. When the horizontal line falls into the confidence interval, the null hypothesis that there is no effect of each of shocks on variables cannot be rejected. Thus, the including the horizontal line for the particular time period can be interpreted as an evidence of statistical insignificance [35].

Figure 2 shows the dynamic effects of oil price on output is weak in the both short-run and longrun, while in the long-run, this effect on inflation is positive and increasing (Figure 3). The aggregate supply has a positive dynamic effect on output and inflation. The dynamic effect of aggregate demand on output is negative, but this effect is positive for inflation (Figures 2 and 3 ).

Figures 4(a) to (f) display the estimated impulse response functions (IRFs). According to the impulse response equations, demand shocks can negatively affect output. In the first 3 periods, the short term impact, output decrease induced by oil price shocks, but in the next 3 periods, the long term impact increases. The effect of supply shocks on output is positive, and to waste after 4 periods.

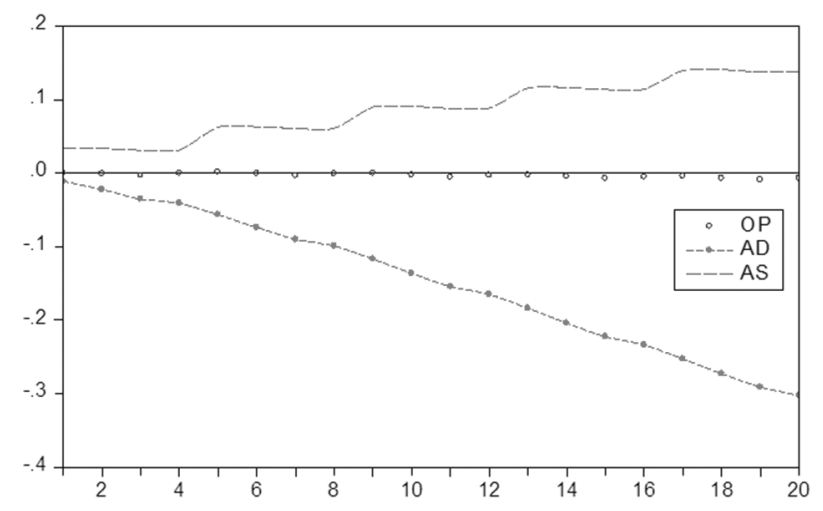

Fig. 2. Response of output to shocks

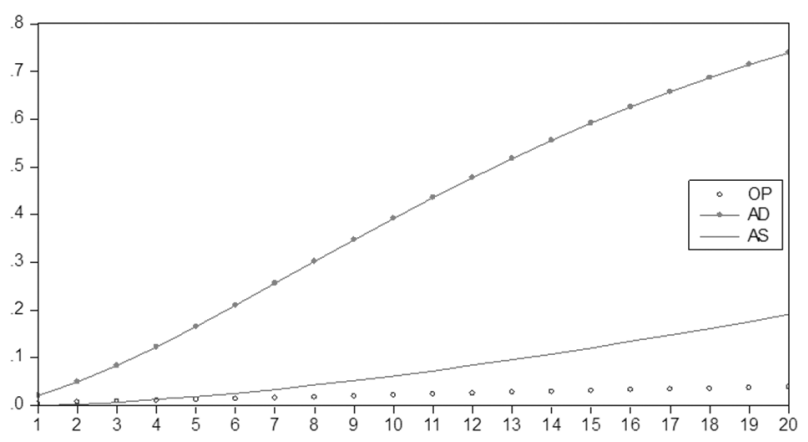

Fig. 3. Response of inflation to shocks 

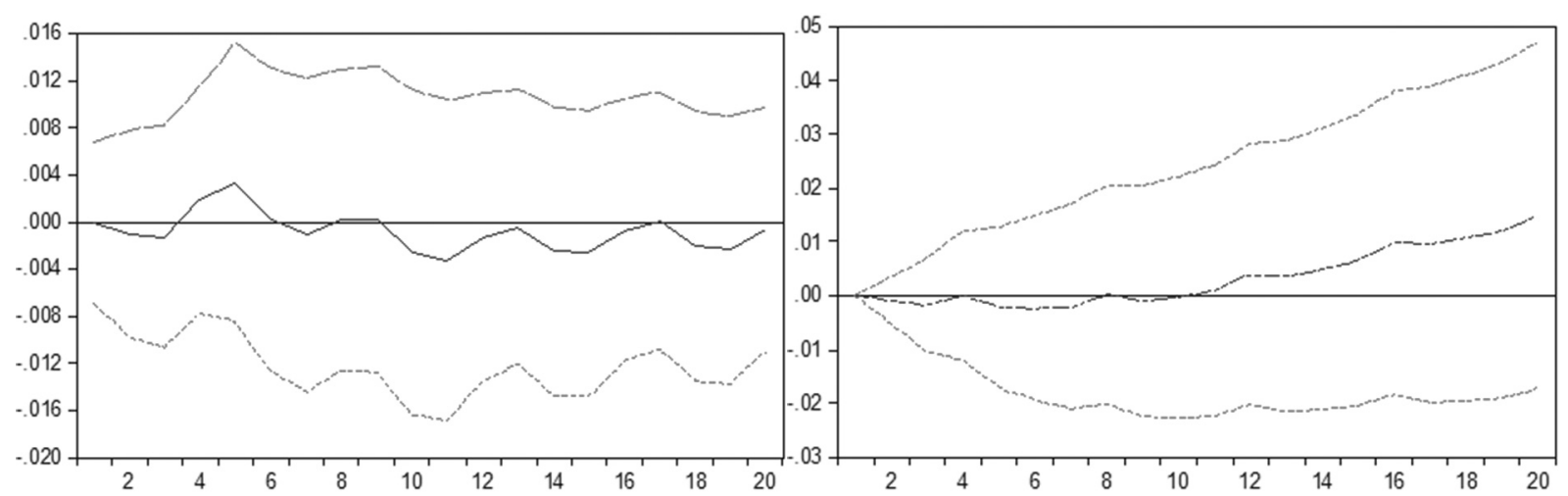

a. Response of output to oil price shocks
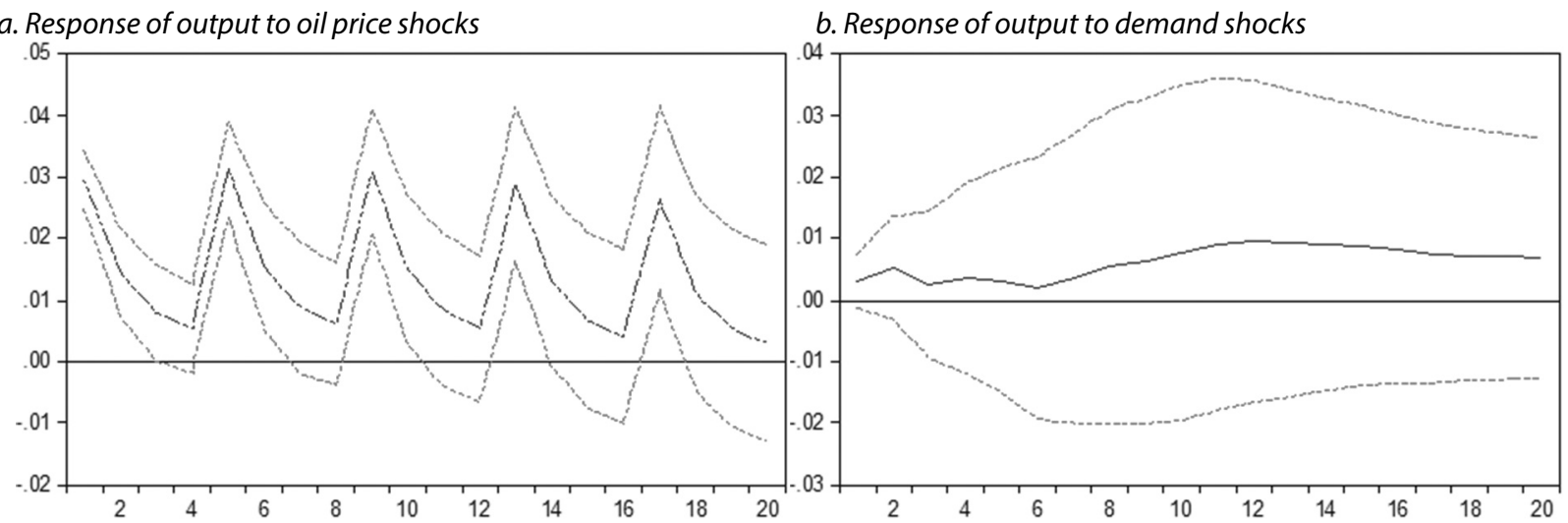

c. Response of output to supply shocks

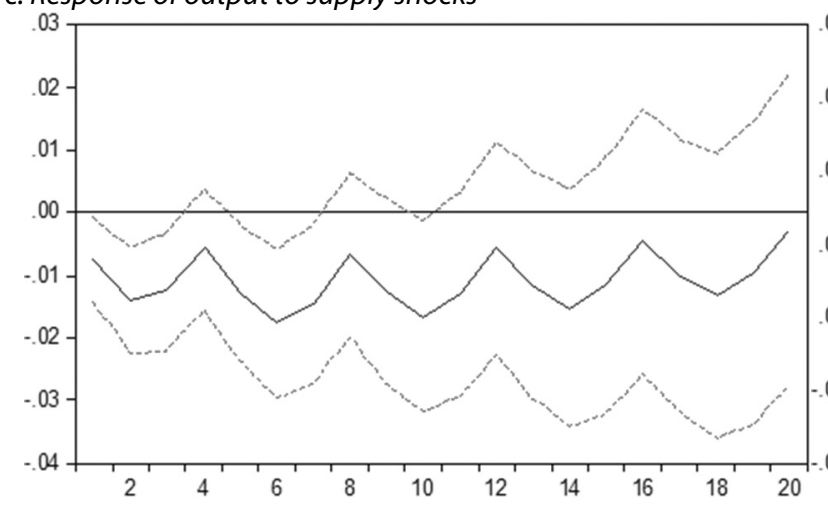

e. Response of inflation to supply shocks

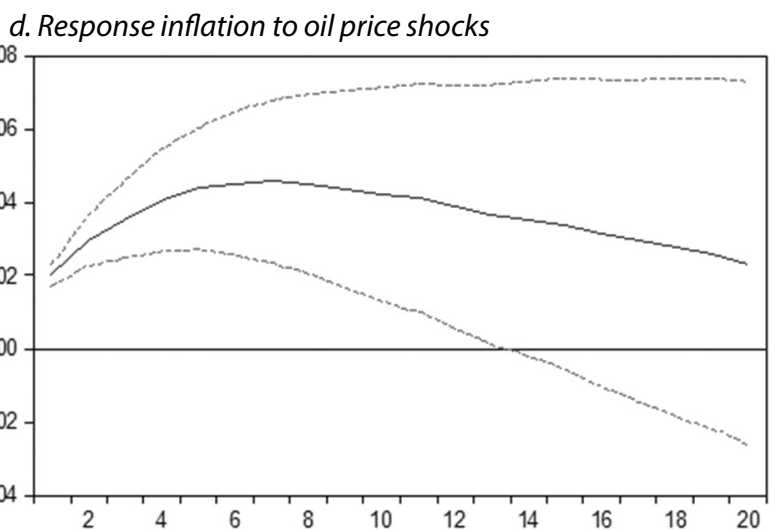

Fig. 4. Impulse response on S.D error band of output and inflation to shocks

The positive effect of supply shocks on output can be seen in the next period.

The effect of oil price shocks on inflation is positive, and can reach a steady state after ten periods. The demand shocks have positive effects and the supply shocks have negative ones on inflation, and remain for a protracted period.

The responses of output and inflation to oil price shocks positive. The response of output to demand shocks is negative and significant, and remains negative until eight periods. The response of output to supply shocks is positive and significant. These results are consistent with the economic theory.

\subsection{Variance Decomposition analysis}

The impulse response functions illustrate the qualitative response of the variables in the system to shocks. To indicate the relative importance of these shocks is required variance decomposition. It allows us to verify how many of the forecast errors changes or variations of the variables in a system are explained by different shocks over a time period. The variance decomposition in this paper is based on structural decomposition (orthogonalization) estimated in the factorization matrices for the identified VAR model. In the following, we use variance decomposition to measure of fluctuations in output and domestic price level caused by oil price, aggregate supply and aggregate demand, respectively.

The results of variance decomposition for output and price level are represented in Table 3. These results show that oil price shocks cause $0.04 \%$ of short-run (second quarter) and $1.06 \%$ 
Variance decomposition of output and price

Table 3

\begin{tabular}{|c|c|c|c|c|c|c|}
\hline \multirow{2}{*}{$\begin{array}{c}\text { Horizon } \\
\text { Quarters) }\end{array}$} & \multicolumn{2}{|c|}{ Variance decomposition of output } & \multicolumn{3}{c|}{ Variance decomposition of price } \\
\cline { 2 - 7 } & OP shock & AS shock & AD shock & OP shock & AS shock & AD shock \\
\hline 1 & 0.01 & 90.19 & 9.79 & 1.98 & 98.01 & 0.00 \\
\hline 2 & 0.04 & 81.14 & 18.8 & 2.00 & 97.6 & 0.39 \\
\hline 4 & 0.85 & 70.09 & 29.04 & 0.73 & 97.51 & 1.75 \\
\hline 6 & 0.68 & 66.96 & 32.34 & 0.46 & 97.76 & 1.77 \\
\hline 8 & 1.06 & 59.86 & 39.07 & 0.35 & 97.08 & 2.56 \\
\hline 12 & 1.11 & 53.42 & 45.46 & 0.29 & 96.01 & 3.69 \\
\hline 16 & 1.09 & 49.11 & 49.78 & 0.27 & 94.52 & 5.2 \\
\hline 20 & 1.07 & 46.1 & 52.82 & 0.26 & 92.62 & 7.11 \\
\hline 24 & 1.05 & 43.87 & 55.06 & 0.25 & 90.34 & 9.4 \\
\hline 30 & 0.99 & 41.96 & 57.04 & 0.25 & 86.49 & 13.25 \\
\hline
\end{tabular}

of long-run (eighth quarter) of output variation. Aggregate supply shocks contribute $81.14 \%$ of changes in output in the short-run, while this share is lower in the long-run (59.86\%). Aggregate demand shocks explain $18.8 \%$ and about $39 \%$ of variations of output in the short-run and long-run, respectively. We conclude oil price shocks have bit share on changes in output in short-run and longrun in Iran. The share of aggregate demand shocks on output variations increases in long-run, while the contribution of aggregate supply shocks decreases in long-run.

The variance decomposition of price shows oil price shocks explain $2 \%$ of price changes (inflation) in the short-run, but this contribution decreases in the long-run. The share of aggregate supply shocks on inflation is $97.6 \%$ in the short- run and gradually decrease in the log-run. Aggregate demand causes $0.39 \%$ of the shortrun variations in price, while this contribution increases in the long-run. Therefore, the aggregate supply shocks have a determinant contribution in variations of the price level (inflation) both in the short-run and the long-run.

\section{Discussion and Conclusion}

In this paper, we studied the effects of oil price, aggregate supply and aggregate demand shocks on output and inflation as macroeconomic variables in Iran's economy. We used a structural VAR model with a mixture of short-run and long-run restrictions. Also, the impulse response and decomposition functions are computed for each variable.

The results show the dynamic effect of oil price shocks on output and inflation in Iran's economy is negative and positive, respectively, but the effect on output is smaller than on inflation. Considering Iran as an oil exporting country, these results are consistent with economic facts. The high share of oil income of exporting in government budget indicates when the oil income increases, the government expenditure and the aggregate demand increase and cause the inflation arise. Also, when the oil price increases, because of uncertainty in the sustainability of oil income, the government cannot provide public firms on the base of given economic plan and usually the output doesn't increase. The government in Iran to reduce the effects of oil price shocks on inflation must decrease the budget dependence to oil incomes, because, the oil price shocks disrupt economic planning and the government has to focus on current expenditure and neglect the investment expenditure to increase in output.

The results indicate the dynamic effects of aggregate supply shocks on output are positive and significant. This result suggests the supply shocks are the main factor inducing fluctuation in output. Given that the effect of supply, we suggest Iranian government to provide the technology transfer for private firms to increase output.

\section{Acknowledgments}

The work is performed in the Faculties of Economics of University of Tehran and Tarbiat Modares.

\section{References}

1. Bruno, M. \& Sachs, J. (1982). Input price shocks and the slowdown in economic growth: the case of UK manufacturing. The Review of Economic Studies, 49, 679-705.

2. Hamilton, J. D. (1996).This is what happened to the oil price-macroeconomy relationship. Journal of Monetary Economics, 38, 215-220.

3. Balke, N. S. \& Brown, S. P. \& Yücel, M. K. (2002). Oil price shocks and the US economy: Where does the asymmetry originate? The Energy Journal, 22, 27-52. 
4. Rasche, R. H. \& Tatom, J. A. (1981). Energy price shocks, aggregate supply and monetary policy: the theory and the international evidence. Carnegie-Rochester Conference Series on Public Policy. Elsevier, 14, \9-93.

5. Hamilton, J. D. (1983. Oil and the macroeconomy since World War II. The Journal of Political Economy, 91(2), 228248.

6. Gisser, M. \& Goodwin, T. H. (1986). Crude oil and the macroeconomy: Tests of some popular notions: Note. Journal of Money, Credit and Banking, 18, 95-103.

7. Darby, M. R. (1982). The price of oil and world inflation and recession, The American Economic Review, 72, 738-751.

8. J. Burbidge, A. Harrison, (1984).Testing for the effects of oil-price rises using vector autoregressions. International Economic Review, 25, 459-484.

9. Mork, K. A. (1989). Oil and the macroeconomy when prices go up and down: an extension of Hamilton's results. Journal of political Economy, 97, 740-744.

10. Hooker, M. A. (1996). What happened to the oil price-macroeconomy relationship? Journal of Monetary Economics, $38,195-213$.

11. Jiménez-Rodríguez ${ }^{\star}$, R. \& Sánchez, M. (2005). Oil price shocks and real GDP growth: empirical evidence for some OECD countries. Applied economics, 37, 201-228.

12. Ferderer, J. P. (1997). Oil price volatility and the macroeconomy. Journal of macroeconomics, 18, 1-26.

13. Huang, B.-N., Hwang, M. \&Peng, H.-P. (2005). The asymmetry of the impact of oil price shocks on economic activities: an application of the multivariate threshold model. Energy Economics, 27, 455-476.

14. Guo, H. \& Kliesen, K. L. (2005). Oil price volatility and US macroeconomic activity. Review-Federal Reserve Bank of Saint Louis, 87, 669-683.

15. Narayan, P. K. \& Narayan, S. (2007). Modelling oil price volatility. Energy Policy, 35, 6549-6553.

16. Rafiq, S., Salim, R. \& Bloch, H. (2009). Impact of crude oil price volatility on economic activities: An empirical investigation in the Thai economy. Resources Policy, 34, 121-132.

17. Kilian, L. (2010). Oil price volatility: Origins and effects. WTO Staff Working Paper.

18. Abeysinghe, T. (2001). Estimation of direct and indirect impact of oil price on growth. Economics letters, 73, $147-153$.

19. Cunado, J. \& de Gracia, F. P. (2014). Oil price shocks and stock market returns: Evidence for some European countries. Energy Economics, 42, 365-377.

20. Ran, J. \& Voon, J. P. (2012). Does oil price shock affect small open economies? Evidence from Hong Kong, Singapore, South Korea and Taiwan. Applied Economics Letters, 19, 1599-1602.

21. Le, T.-H. \& Chang, Y. (2013). Oil price shocks and trade imbalances. Energy Economics, 36, 78-96.

22. Ebrahimi, M., Zarini, E. \& Haji Mirzaei, M. (2010). The oil price fluctuation and it's effect on macroeconomic variables (1988-2007). Economic Policies, 6, 89-106.

23. Nemati Allahi, F. \& Majd Zade Tabatabaei, S. (2009). The effect of OPEC oil price fluctuation on Iranian trade balance. Economic Modeling Quarterly, 4, 151-169.

24. Shakibaei, A., Aflatoni, A. \& Nikbakht, L. (2008). The analysis of long run realtionship between exchange rate and oil price in non-OPEC countries. Knowledge and Development Journal, 25, 68-85.

25. Jahadi, M. \& Elmi, Z. (2011). Oil price shocks and economic growth (evidences from OPEC countries). Economic Growth and Development Researches, 1, 11-42.

26. Hadian, E. \& Parsa, H. (2006). The analysis of oil price fluctuations on Iran's macro-economy. Human and Social Researches, 22, 111-132.

27. Central Bank of Iran (CBI). (2015). The summary of economic developments Central bank of Iran. Tehran, Iran, 158.

28. Lucas, R. E. (1972). Expectations and the Neutrality of Money. Journal of economic theory, 4, 103-124.

29. Lucas, R. E. (1973). Some international evidence on output-inflation tradeoffs. The American Economic Review, $326-334$.

30. Bjørnland, H. C. (2000). The dynamic effects of aggregate demand, supply and oil price shocks-a comparative study. The Manchester School, 68, 578-607.

31. Blanchard, O. J. \& Quah, D. (1993). The dynamic effects of aggregate demand and supply disturbances: Reply. The American Economic Review, 653-658.

32. Sims, C. A. (1980). Macroeconomics and reality, Econometrica. Journal of the Econometric Society, 1-48.

33. Bernanke, B. S. \& Mishkin, F. S. (1997). Inflation targeting: a new framework for monetary policy? National Bureau of Economic Research, 2-Spring, 97-116.

34. Blanchard, O. J. \& Quah, D. (1989). The dynamic effects of aggregate demand and supply disturbances. The American Economic Review, 79, 655-673.

35. Berument, M. H., Ceylan, N. B. \& Dogan, N. (2010). The impact of oil price shocks on the economic growth of selected MENA countries. The Energy Journal, 149-176.

\section{Authors}

Sajjad Barkordari - PhD in Economics, Assistant Professor, Faculty of Economics, University of Tehran (North Karghar Street, Tehran, Iran: e-mail: barkhordari@ut.ac.ir).

Maryam Fattahi - PhD in Economics, Academic Member, University of Tarbiat Modarese; Science and Research Branch, Islamic Azad University (098, Amir Abad, Tehran, 1423464971, Iran: e-mail: maryam2004@gmail.com). 